\title{
EFFECTS OF SELF MONITORING AND MANAGEMENT STRATEGY ON VIOLENT BEHAVIOURS AMONG SENIOR SECONDARY SCHOOL STUDENTS WITHIN BIDA EDUCATIONAL ZONE OF NIGER STATE
}

\section{Y. UMARU (PhD)}

\begin{abstract}
The study examined the Effect of Self-monitoring and Management Strategy on Violent Behaviour among senior secondary School Students. It was guided by two research questions and two hypotheses. A nonequivalent control group Quasi-experimental design involving one treatment and one control group was adopted. A total of 43 senior secondary schools (SSII) classes with high record of Behavioural problems in School within Bida Educational Zone of Niger State were used for the study. The instrument used for the study was the Adolescent Behavioural Assessment (ABA) which was validated by experts and used for data collection. Mean, Standard deviation and Analysis of Covariance (ANCOVA) was used to analyze the data collected. The results suggested that the use of self monitoring and management strategy are efficacious in reducing violent behaviours in schools. Based on the findings, the introduction of peace education in schools to curb the effect of violent behaviour on academic and social development and school psychologist or counselors' training on the new strategies to reduce violent behavior in school are among the recommendations proposed by this study.
\end{abstract}

\section{Introduction}

The use of violent behavior is increasing alarmingly in our schools and society. Students use violence in their classes, dormitories, assembly grounds and even playgrounds. Violent behavior is the brutal use of force on self, others or on properties facilities in the schools. Psychologists point to potential warning signs that might avert future tragedies. Adolescents who are likely to commit violence often refuse to listen to authority figure, such as parents, and teachers, ignore the feelings and rights of others; mistrust people, rely on violence or threaten violence to solve problems; and believe that life has treated them unfairly. They often look older than their peers. They tend to do poorly in school; cut classes or $\mathrm{p}$ ay truant; be held back or suspended or dropout; use alcohol, inhalants and or drugs; joi 1 gangs; and fight, steal or destroy property (Papalia, Olds and Feldman 2010; American Psychological Association and America Academy of Pediatrics (AAP), 1996 \& Resnick, 1997).

This could also be in form of competitive behavior such quarreling, riot, hooliganism, vandalism (Obikezie and Odomelan, 1996) as well as stigmatization, labeling, violent sexual escapades and antagonism among many other instances.

While students may have very good reasons for using violence, the researcher is of the opinion that the consequences that follow the use of violence out weight those 'good reasons' for getting involved in violence. The researcher had witnessed some school infrastructure to include library, principal offices, the staffrooms so wantonly destroyed by the students of a neighbouring school for what the students termed disrespect for the 
school, having been beaten in a football match competition. He also witnessed the embarrassment of a teacher and the principal beaten up by the students of the secondary school where this research was carried out.

The Nigeria's news media are replete with stories of similar incidences. The vanguard publication of $10^{\text {th }}$ August, 1999 reported a brutal murder of the Assistant Register of Delta State University by hoodlums believed to be students of that institutions; The Daily Trust publication of $18^{\text {th }}$ October, 2011 reported also the killing of a 200 level student of College of Education Minna by hoodlums believed to be students of the colleges, similarly. The Daily Trust publication of $3^{\text {td }}$, October 2011 reported the cases of rioting at Federal Polytechnics Bida following the alleged disappearance of genital organ of a student that escalated to rampage by students destroying school properties which resulted to the closing down of the institution by the authority. All these cases cited, stand as solid to justify the prevalence of violence in our schools.

Presence of violence in man is said to be as a result of diverse factors some of which are aberration in the chromosomal distribution, seen in possession of XY chromosomal compositions, unguarded production of testosterones, brain damage and disease, size and even the shape of one's feet (Johnson, 1992) and gender as reported by Mbajigu (1991).

Psychological causes like displacement, where man is said to aggress or destroy in order not to self-destroy, have been given as one of the causes of violence. Freud (1968) in Frommy's, Anatomy of Human Restrictiveness. Related to that is Lorenz (1996) proclamation that man's use of violence is inherent and innate in him being a victim of a genetically programmed anomaly which inhibit the mechanism of specie-preservation in man making and a species of rat the only animals that aggress and even kill their kind. No wonder some anthropologists see man's inclination to violence as a left over of his carnivorous psychology acquired in his primitive age and a consequence of human trauma learning acquired during competitions over territories, scarce resources and frustration due to non or under achievement, chemical composition of food eaten, as well as man's socialization with user of violence. Even exposure to media (TV) where violence is lavishly used might be a cause of violence for users of violence. Since these last factors attribute the acquisition of the use of violence to learning, the researcher is of the view that the inclination and the use of violence can be unlearned using SelfMonitoring and Management strategy.

Self-Monitoring describes a process of the student assessing whether or not he has performed a particular behavior and then recording the result. Self Monitoring requires the student to self-assess and self record accurately. Two different types of self monitoring are often employed. The students may be asked to self-record their attention to the task or their academic performance (Reid, 1996). In Self-Monitoring attention to task, the student is asked to record whether or not they are paying attention and to selfrecord when cued. These cues usually are given by a tape recording which sounds a beep at a variable interval during the students work period in the classroom. The student may then be instructed to mark a chart for every interval and to tally the number of intervals of 'paying attention at the end of the work time. In the self monitoring of academic 
performance, the student is asked to record productivity, (how many problems completed); accuracy of responding (how many correct) or whether or not the student has followed the steps in a particular strategy. Once again the student may be cued by the teacher, or a tape recorder sounding a variable signal to self-record, whether or not he is performing the behavior of interest. Student using either the strategy of self-recording attention to task or self-monitoring academic performance often use charts, graphs or tally sheets to record their performance (Copper, Heron and Heward, 1987).

Self monitoring has been shown to increase accuracy over didactic instruction plus reinforcement. Numerous studies have demonstrated the usefulness of self-monitoring procedures with a range students (Copper, Heron and Heward, 1987, Reid 1996).

This approach is much more appropriate when a student accepts that a pattern of behavior is inappropriate and is desirous to change. Students, who learn to self-regulate their own behavior has been found to be more determined, posses higher self-efficacy and are intrinsically motivated to learn and achieve success in the classroom. (Eze, 2009). They engaged more in productive classroom activities and as such teachers are relieved of the function of frequently monitoring the students as they set more time to engage in other activities that will promote classroom.

There are guidelines for teaching students to use self-monitoring programme among which include: Identify target behaviours, Discuss target behaviours with students, Select a way to measure behavior, Train students to use the measurement system, Once the student is using the system do accuracy check, and Provide feedback (Copper, Heron and Heward, 1987).

Self-management strategy on the other hand is the outcome of a person systematically using behavior change strategies to change their own behavior technically, to qualify as self-management, the person must plan the strategy, implement the strategy by reinforcing or sometimes punishing their own behavior and evaluating the contained of the self-manag ment strategy (Nelson, Smiths, young, and Dodd, 1991). Effective classroom manigement strategies that promote appropriate behavior; aid appropriate learning responses and competency in group activities that ensure learners active involvement and interest in learning situation is enhanced using management strategy (Lami, Cole, Shampion \& Bambara 1994)

It is also a behavioural technology through which a person directs and maintains his unwanied behaviours in order to produce desired and desirable effects. It has been variously named self regulation, self control and self restrain method. Self management strategy is based on Skinner B.F. (1953) exposition and the use of operant conditioning (Cooper, Heron and Heward 1987). These strategies may include: observation of ones own behavior, recording that behavior, monitoring the behavior, and delivery of consequences. The last step must be followed in a contractual manner and never relinquishes till near habituation of the target behavior. The self- management is a private procedure and do not forget that the self-management programme should be faded as soon as the students behavior has improved and maintained. 


\section{Statement of the Problem}

The use of violence and Misbehaviors in our school is almost turning our schools into sub-culture of hostility and antagonism. Teaching and learning is often disrupted, lives and properties are no longer safe in our various schools as lecturers, teachers, principals, head teachers and even students are intimidated by violence. Thus, the study sought to find out the effect of "Self monitoring and management strategy on violent behavior among senior secondary school students within Bida educational zone of Niger State".

\section{Scope of the Study}

The study was carried out among senior secondary school students within Bida Educational zone of Niger State. whose use of violent behavior was managed using SelfMonitoring and Management strategies.

\section{Research Question}

i. What are the effects of Self-Monitoring and Management strategies in reducing violent behavior in treatment and untreated group?

ii. What are the difference in the efficacy in the measure of Adolescent Behavioural Assessment (ABA) of student exposed to Self-Monitoring and Management strategy?

\section{Hypotheses}

This study was guided by the following hypotheses that were tested at 0.05 level of significance.

$\mathrm{HO}_{1}$ : There is no significant difference of self monitoring and management strategies in reducing violent behavior in treated and untreated subject.

$\mathrm{HO}_{2}$ : There is no significant difference in the efficacy of Self-Monitoring and the Management strategies in reducing violent behavior in the subject.

\section{Method}

This study is a non-equivalent control group quasi-experimental design involving one treatment and one control group.

\section{Population of the Study}

The population used for this consisted of all the 43 senior secondary two students (SS2) with high record of behavioural maladjustment such as (truancy, fighting, bullying, quarrelling among others) in school within Bida education zone of Niger State were used for the study. 


\section{Sample and Sampling Techniques}

The sample consisted of 43 senior secondary two students (SS2) drawn from two coeducational secondary schools in Bida Educational Zone of Niger State. Their average age was 14.9 years. Purposive sampling technique was used to select one male and one female secondary schools having SS2 class with at least two streams. In each of the school sampled, two intact classes of SS2 were randomly selected, and each school were tagged the treatment and control classes using simple balloting.

The first class to be drawn was named the treatment group while the second class automatically became the control group.

\section{Instrument for the Study}

The Adolescent Behavioural Assessment (ABA) was used for this study. It is a four point scale meant to determine the Adolescent efficacy of violent behavious in schools. The scale ranges from Strongly Agree (SA), Agree (A), Strongly Disagree (SD) to Disagree (D). The items were developed from information acquired through review of relevant literature.

\section{Validation of the Instrument}

The ABA developed by the researcher was faced validated by three experts in Educational Psychology, measurement and evaluation, and Guidance and Counselling for the criticism and inputs relating to the appropriateness of the items and clarity of language. The inputs of these experts contributed to the final form of the instrument that was used for this study.

\section{Reliability of the Instrument}

The instrument was trial tested by Administering it to 30 SS 2 students drawn from Senior-secondary school in Gwagwalada Area Council of FCT Abuja. The internal constituent reliability estimate of the instrument was determined using the Cronbach Alpha method and the reliability estimate is 0.85 . in order to determine the stability of ABA overtime, a test-retest analysis using Pearson correlation method was conducted and a Pearson of 0.77 was obtained. This was necessary since the same ABA, though to be reshuffled, was used for both pretest and posttest.

\section{Treatment Procedure}

Before the commencement of the training, the trainer familiarized themselves with the subjects to ascertain whether student experience violent problems in school. This, was believed helped the trainer in determining how best to motivate the subject to acquire the new strategy. 
- Immediately after assigning the subject to treatment and control groups, the pretest was administered to them. Instructional strategies on Self -Monitoring and Management were taught to those in treatment groups. All these were done through the following: Biographic histories of non violent personalities, civility recitation environment, changing skills and contractual; fulfillment; modeling of good behavior; reinforcement skills and evaluation of feedback, respectively. While the control group, were only being exposed to the normal classroom management (punishment) in reducing violent behaviours.

The trained research assistants who are school counselors were used. Each one handle the treatment and the control group respectively. This will had helped to minimize the teacher effect. The study lasted for four weeks through which scores are gathered for the pretest and the post-test.

\section{Method of Data Analysis}

The data collected by administering the various research hypothesis were collated, organized, and analysed using mean and standard deviation and analysis of covariance (ANCOVA) was used to test the hypothesis at 0.05 level of significance.

\section{Result}

Table 1: T-Analysis Difference of Self Monitoring and Management Strategies in Managing Violent Behaviour in Treated and Untreated Groups

\begin{tabular}{|c|c|c|c|c|c|c|c|c|}
\hline Subject & $\mathrm{N}$ & $\mathrm{X}$ & SD & $\mathrm{DF}$ & $\mathrm{t}$-cal & t.crit & $P$ & Decision \\
\hline $\begin{array}{ll}\text { lA } & \text { self } \\
\text { monitoring } & \\
\text { group } & \end{array}$ & 11 & 113.7273 & 30.70534 & \multirow{4}{*}{20} & \multirow[b]{3}{*}{.522} & \multirow{4}{*}{1.96} & \multirow{4}{*}{.607} & \multirow{4}{*}{ NS } \\
\hline Control group & 11 & 113.7023 & 30.70534 & & & & & \\
\hline $\begin{array}{l}\text { IB management } \\
\text { group }\end{array}$ & 11 & 119.7273 & 22.60129 & & & & & \\
\hline Control & 10 & 108.6000 & 23.58059 & & .522 & & & \\
\hline & & & & 20 & & 1.96 & .608 & NS \\
\hline
\end{tabular}

NS = not significant

The calculated t-valued was .522. This value was tested for significance by comparing it with the critical t-value at 0.05 level with a 20 degree of freedom. The calculated t-value was less than the t-value. Hence, the result was not significant in self-monitoring and management strategies in managing violent behavior in treated and untreated group. Therefore Ho, was accepted.

$\mathrm{HO}_{2}$ : Seeks to find if there is no difference in the efficacy of the two packages: The self monitoring and management strategy.

Table II: $\quad$ Showing Difference in Efficacy Treatment

\begin{tabular}{lllllllll}
\hline Subject group & $\mathrm{N}$ & Mean & $\mathrm{SD}$ & $\mathrm{DF}$ & $\mathrm{t}$-cal & $\mathrm{t}$-cri & $\mathrm{P}$ & Decision \\
\hline Self monitoring & 11 & 113.7273 & 30.7053 & & & & & \\
Self management & 11 & 119.7273 & 22.6012 & 20 & .522 & 1.96 & .607 & NS \\
\hline
\end{tabular}


The $t$-cal value of .522 is obviously less than the t-crit value of 1.96 showing that there is no significant difference in the two tools. By this both tools are efficacious in reducing violent behaviours in schools. Hence the null hypothesis is accepted.

\section{Discussion}

The result of this study shows that the use of psychological intervention strategies are effective management tools for reduction of violent behaviours in school. This is suggested by the fact that the two treatment groups are efficious in reducing violent behaviours among adolescent in schools than the untreated control group with a mean difference of 117.2273 and 112.1512 respectively. These strategies help learners to think more effectively, managed conflict by themselves, engage in practical thought, experiment and question their basic assumptions.

This finding is in line with the findings of Obiekezie and Odomelam (1996) Denga (1986), (Copper, Heron and Heward, (1987), and Reid (1996) who used self monitoring, management cognitive process in managing deviant behaviours among school children.

Self-Monitoring as a self-regulatory strategy is especially important as it enables students to monitor and record the frequency of occurrence of inappropriate behavior and take required steps to control the occurrence of such behavior.

Students exposed to instruction in using self-management strategy are also able to judge their own behavior as appropriate or inappropriate; can spend more time in teaching tasks and learning as well as ability to manage their own behavior which may facilitate generalization and maintenance of newly acquired skills in inclusive setting than those who are not exposed to the use of this strategy.

\section{Implication of the Study and Conclusion}

This study will add to theory building on behavior modification techniques. Essentially on self monitoring and management strategies in reducing violence behaviours in schools. This will facilitate appropriate behavior in school setting and community general. If this study is replicated, it will also serve as missing link to other researchers.

It is thus, a humble opinion that if this study is carried out in many institution and communities where violence and many other related vices are robbing us of peace, lives and properties will be less troubled by violence. This will lead to more productive lives and happier societies. Riots and wanton destruction will be a thing of past. Accordingly, these call for urgent action, by heads of institutions.

\section{Recommendations}

The following recommendations are made from the findings of this study that: 
1. Peace education should be introduced in our schools on the effects of violent

- behavior on academic and social development.

2. School Psychologist/ counselors in schools should be trained and retrained on the new strategy in managing devient behaviours in schools

3. The school psychologist, counselors, special educators, and social worker should encourage the use of this strategy (self monitoring and management strategy) in reducing violence behaviours in schools.

4. Child friendly environment be created in schools.

\section{References}

Amajironwu, S. (1981). Approaches to the Controlling of Problem Behaviour in Primary Schools. Alvan College of Education Journal 1 (2) Owerri.

Adejuwon G. A. \& Ibeagha P. N. (2005). Adolescent Behavioral Outcome Scale: Development and Vchvalm in Ibadan, Nigeria. Journal of Social Science: 123-127

Copper, J. O.; Heron T. E.; Heward, W. L. (1987). Applied Behaviour Analysis, Columbus, Ohio: Merrill.

Fromm, E. (1973). The Anatomy of Human Restructiveness: Jonathan Cape Ltd.

Hamagam A. M. Daily Trust October 3, 2011 retrieved on 11/11/11 at www.nigerianewshine.comm/Nigerian-fed.

Hamagam A. M. Daily Trust October 23, 2011 retrieved on 25/11/11 at www.com/p/J 29K Minna

Igboanugo, S. The Guidance September, 1998 p.13

Johnson, W. (1972). Aggression in Man and Animals. Philadelphia: W.B Sanders Company Ltd.

Lam, A. L.; Cole, C. L.; Shapiro, E. S. \& Bambara, L. M. (1994). Relative Effects of Self-Monitoring on-Task Behaviour, Academic Accuracy and Disruptive behavior in Students with Behaviour Disorder. School Psychology Review, 23 (1): 44-58.

Nelson, J. R.; Smith, D. J.; Young, R. K. \& Dodd, J. M. (1991). A review of selfmanagement outcomes research conducted with students who exhibit behavioural disorders, Behavioural Disorder, 16 (3): 169-179.

Obeikezie, M. C. and Odoemelam, A. (1998). Management of Violent Behaviour in Schools. Immunize Journal of Education and Technology: 98-105.

Reid, R. (1996). Research in Self-Monitoring with Students with Learning Disabilities: The Present, the Prospects. The Pitfalls. Joumal of Learning Disabilities. 29 (3): 317 331.

Skinner, B. F. (1953). Science and Human Behaviour. New York: Macmillan.

Eze U. N. (2009). Managing Behaviour in the Classroom: Applying Psychological Principles. Enugu. Timex Publisher. 